\title{
Community Leaders' Perceptions toward Tourism Impacts and Level of Community Capacity Building in Tourism Development
}

\author{
Fariborz Aref \\ Department of Social and Development Sciences \\ Faculty of Human Ecology, Putra University, Malaysia \\ Tel: 60-1-2299-9594 E-mail: fariborzaref@yahoo.com \\ Ma'rof Redzuan \\ Department of Social and Development Sciences \\ Faculty of Human Ecology, Putra University, Malaysia \\ E-mail: marof@putra.upm.edu.my
}

\begin{abstract}
This paper attempts to identify the relationship between the community leaders' perceptions toward tourism impacts and their effort in building the capacity for tourism development in local communities of Shiraz, Iran. The paper is based on the study carried out among 175 communities' leader. The analysis of data uses Pearson correlation to determine the relationship between variables involved. The findings reveal that two impacts (economic and environmental) have the most significant relationship with the level of community capacity building. The findings of the study imply that those leaders who perceived the tourism activities could bring economic benefits would have the higher tendency to be actively involved in building the capacity of their communities in relation to the development of tourism, whereas those who perceived tourism could bring negative impact to the environment, would put less effort in the capacity building.
\end{abstract}

Keywords: Community perception, Tourism impacts, Community capacity building, Local communities

\section{Introduction}

In many countries, tourism is a fast growing industry and a valuable sector. Tourism contributes significantly to the countries' economy. Moreover, tourism plays an increasingly important role in the development of communities. The benefits of tourism include both tangible (e.g. job creation, state and local tax revenue, etc.) and less tangible (e.g. social structure, quality-of-life, etc.). In addition, tourism can, and often does, result in less desirable effects on the economic, social, and environmental fabrics of communities. These benefits and costs provide ample opportunity for creative public policy debate. In other words, tourism affects the economy and lives of communities. There are real and perceived fears that are sometimes attributed to tourism. These impacts of tourism on communities could influence the communities' effort to develop the industry. In relation to this, the main focus of this paper is to identify the relationship between communities' perception towards the impacts of tourism and their effort to build their community capacity in relation to tourism development.

Community perception towards the tourism impacts on a community can vary significantly. According to Sharma (2004), positive attitudes towards tourism impacts among communities residents will result in more successful tourism development. Thus, understanding the community perception can help to access community support for continued tourism development through community capacity building. Gursoy \& Rutherford (2004) suggested that tourism developers need to consider the perception and attitude of residents before they could start investing scarce resources. Moreover, understanding of community perception towards tourism impacts can also help to identify types of tourism which have the potential for building community capacity (Moscardo, 2008, p. 86). Meanwhile, several studies indicate that people who have an economic gain from tourism perceive more positive impact from it (Chon, 2000). In this present study, it is assumed that community perception towards tourism impacts does have a considerable effect on the level of community capacity building in tourism development. In the study, the researchers employ exchange theory in order to explain the relationship between perception towards tourism impacts and the level of community capacity building. Tourism has been proved as one of the most ingeniously crafted and expedient opportunities for social exchange (Singh, Timothy, \& Dowling, 2003). Thus, in this study, social exchange theory is considered as a conceptual sociological approach to the study of leaders' perceptions towards tourism impacts and its relationship with their effort 
for community capacity building in tourism development. However, the researcher did not find any study about the relationship between the perceptions towards tourism impacts and level of community capacity building.

\section{Literature review}

The tourism industry has human and environmental costs, besides its benefits to communities involved. Thus, some communities have to make a choice whether to adopt tourism or reject it as a source of income. For the communities which adopted tourism as one of the development alternatives, they would put more effort in developing the tourism industry. Some local communities would attempt to build their community capacity in relation to tourism development. Community capacity building can be seen as the capacity of community residents to participate in community development activities, both as individuals and through groups and organizations. In relations to tourism development, community capacity building is a necessary condition for improving the process of tourism development and enhancing its benefits for local communities. Hence, the main objective of this study is to investigate relationship between community leaders' perceptions of tourism impacts and their effort for building capacity in tourism development.

A number of theories have been suggested to explain the nature of residents' perception towards tourism impacts and their support to tourism development. Among the theories are conflict theory, community attachment theory, dependency theory, and social exchange theory. However, most of studies utilize the social exchange theory, which has been considered as the most appropriate framework to develop and understand community residents' perception (Ap, 1992). Social exchange theory is used predominately in the literature on assessing tourism impacts for a particular destination (Andereck \& Vogt, 2000; Andriotis, 2005; Ap, 1992; Chen, 2000, 2001; Gursoy et al., 2002; Vogt \& Jun, 2004). Social exchange theory can strengthen the belief that a need exists to measure the level of active participation of community residents in the community development planning process associated with tourism development (Wang \& Pfister, 2008). In the tourism literature, a number of studies have utilized the social exchange theory to explain community perception and reactions to tourism development (Ap, 1992; Jurowski et al., 1997; Yoon et al., 2001). Most of these studies evaluate community residents' perception and assessments of cost and benefits of tourism and their effort for further tourism development in their particular regions. The social exchange theory explains how people react and support tourism development (Ap, 1992; Yoon et al., 2001). In other words, social exchange theory supports that community residents calculate the costs and benefits of tourism development, and their effort for tourism development depends on the outcome of this cost-benefits calculation (Andriotis, 2005). Moreover, according to Andriotis \& Vaughan (2003), social exchange theory allows the investigation of positive and negatives perception towards tourism impacts in a community. It is more than likely, that residents will be aware of the positive and negative implications of tourism and whether to support or not to support the tourism development is based on their perception of the benefits and costs (Andriotis \& Vaughan, 2003). Thus, in the present study, social exchange theory could explain the relationship between community perception towards tourism impacts and their action to get involved in the community capacity building in tourism development. The Figure 1 illustrates this issue.

Tourism industry not only provides means of recreation to the tourists but offers assistance to the ailing and developing economies of the world. Many countries depend on tourism for income. The entrepreneurs, communities and states find immense commercial opportunities in tourism and have made intense efforts to reap the benefits. The net result is the generation of wealth. But this wealth generation is not without a price. For the development of tourism, environment, societies and cultures at the destination has paid a heavy price. The present cause of concern is not only the development but to tackle the challenges posed by development (Chaudhary et al., 2007). In the case of the impacts of tourism, Ming and Wong (2006) have studied the homestay operators perception towards the tourism impact on their community and how their social demographics influence their perception towards tourism. Using factor analysis the impacts on the local community perceived by the homestay operators were condensed into seven factors: economic impacts, the interaction between tourism and other sectors, life quality improvement, general physical environment deterioration, beach degradation, sea water pollution, and interruption to quiet life. However, the economic and social impacts of tourism are a big subject that cannot be covered thoroughly here. Economically, tourism can create jobs for local people and bring money into the country. Since tourists spend money on travel, hotels, food, entertainment and recreation, they can be an important source of income and thus of economic development for the communities with few other possible sources of revenue. Meanwhile, a study by Nyaupane and Thapa (2006) indicates that generally, on comparison of descriptive and statistical analyses, local residents were consistently more likely than managers to perceive fewer negative and greater positive impacts of tourism on the environment. Quite a number of studies are related to the studying the impacts of tourism, however, seldom could we find studies that deal the relationship between community leaders' perception towards tourism impacts and community capacity building in relations to tourism development.

\section{Research Methodology}

The study was carried out in 175 local communities in Shiraz. Shiraz is the capital of the Iranian province of Fars, the ancient homeland of the Achemenian (ca.549-330 B.C.E) and the Sassanian (ca.224-651 C.E) dynasties. The Greeks 
called this area Persia, from which came their beloved national language, Farsi, from the name of this province (Limbert, 2004, p. 3). Shiraz is a central area for Persian civilization and culture. Shiraz has a population of more than $1,000,000$ people. It is situated in the south western region of Iran, in the inlands of about $200 \mathrm{~km}$ from the Persian Gulf at an elevation of 1,800 meters above sea level. Shiraz also is one of the most popular cultural tourism destinations in Iran with a long interesting history of the Roman Empire (Cultural Heritage News Agency, 2006). Throughout history, foreign visitors to Shiraz have praised the city's gardens, its site, its clear air, its wines, and the charm of its people. Iranians themselves, however, have long treasured Shiraz as a city of Islam. Its traditional Iranian name is Dar al -Elm (Abode of Knowledge) (Limbert, 2004).

The data for this study were collected from community leaders. Community leadership was identified as a key factor in developing tourism in local communities (Aref \& Ma'rof, 2009; Moscardo, 2008). According to Eyler et al. (1999), Thompson et al. (2000), and Von et al. (1992) community leaders are able to speak for the community because of their knowledge and their roles in the community. For this study, community leader is defined as those who can influence policy, or opinion, or action on community because of their roles and positions in the community (Aref et al., 2009). For the purpose of this survey, questionnaire was designed for data collection. Moutinho (2000) believed that questionnaire is the most commonly used in tourism marketing research. The items in the questionnaire for this survey were measured using Likert scale. The Likert scale commonly used in marketing research (Grover \& Vriens, 2006). Pearson Coefficient Correlation was used to measure relationship between the variables. Pearson correlation statistic is a statistical technique to measure the strength of the association that exist between two quantitative variables (Ary et al.,1996). The purpose of the study is to measure the strength of relationship between two main variables (the perception towards the tourism impacts and the level of community capacity building). In statistics, correlation (often measured as a correlation coefficient) indicates the strength and direction of a linear relationship between two random variables. In this study community capacity building is a composite variable, consisting of eight domains, namely, participation (7 items), community leadership (6 items), community structure (5 items), skill and knowledge (5 items), community power (5 items), sense of community ( 7 items), resource mobilization ( 5 items) and external support (5 items). Meanwhile, there are three variables of tourism impacts, namely social-cultural impact (10 items), environmental impacts (5 items), and economic impacts (5 items). The study used Likert-scale to measure every item. In the analysis, the community capacity building variable was correlated with the three variables of perception of tourism impacts in order to determine the strength of their relationships. Meanwhile, descriptive statistics were applied to describe the variables understudied.

\section{The findings of the study}

As have been mentioned above, the main objective of the study is to determine the relationship between community leaders' perception towards tourism impacts and their effort for community capacity building in tourism development. Pearson correlation was used to identify these relationships. Table 1 shows the findings of the study in relations to means and standard deviations of the studied variables. For the three variables related to impacts of tourism (environmental, economic and socio-cultural), the data reveal that generally, the leaders have high perception scores for every variable. This is reflected by the means of every variable - socio-cultural impacts $(\mathrm{M}=37.77, \mathrm{SD}=3.114)$, environmental impacts $(M=17.45, S D=2.935)$, economic impacts $(M=17.24, S D=2.346)$, and total impacts $(M=72.46, S D=6.002)$. These findings imply that most of the leaders have agreed with the impacts of tourism on the economy, environment and socio-cultural of their communities. Moreover, the standard deviations reflect that there are relatively small deviations (differences) between respondents (leaders) in terms of their perceptions towards the impacts of tourism. Meanwhile, the mean of leaders' effort of community capacity building in relation to tourism development is relatively low $(\mathrm{M}=129.47, \mathrm{SD}=19.445)$. It implies that majority of the leaders have less effort in the development of tourism activities. In Iran, tourism industry is not one of main focuses of development of the country. Thus, it is understood that majority of the communities in Iran have given less focus on the development of the industry.

The second analysis for this paper focuses on the relationships between the perception towards tourism impacts and the effort of community capacity building in relation to tourism development. The results of the analysis are shown in Table 2. The correlation between socio-cultural impacts and level of community capacity building is found to be non significant ( $\mathrm{r}=-.092, \mathrm{~N}=175, \mathrm{p}=.224$, two-tailed). Meanwhile, the correlation between economic impacts and the level of community capacity building is found to be positively significant $(\mathrm{r}=.252, \mathrm{~N}=175, \mathrm{p}<.001$, two-tailed), whereas the correlation between perception towards environmental impacts is negatively significant $(\mathrm{r}=-.257, \mathrm{~N}=175$, $\mathrm{p}<.001$, two-tailed). Lastly, the correlation between the overall (total) perception of the tourism impacts and the level of capacity building is statistically non significant $(\mathrm{r}=-.075, \mathrm{~N}=175, \mathrm{p}=.325$, two-tailed).

When comparing the socio cultural, environmental and economic impacts of tourism and total tourism impacts descriptively, economic impacts show positive relationship with the level of community capacity building in tourism development. However, environmental impacts have negative significant relationship with community capacity building in tourism development. These findings support the assumption that the communities will support the tourism 
development if the development bring about benefits, such as economic benefits that outweigh the costs of sharing environmental and social resources with tourists (Harrill, 2004). In addition, Martin et al (1998) found that retirees were less supportive of tourism development and identified more with the negative impacts of tourism. They conclude that those who did not receive real economic gain from the tourism growth would not support further development. The findings from this study supported the previous studies in terms of positive tourism impacts and their support for tourism development. The findings of studies related to economic impacts are consistent with the past studies that have been conducted by Ap (1992) and Yoon et al (2001). These studies evaluated community residents' perception and assessments of cost and economic benefits of tourism and their support for further tourism development in their communities.

Social exchange theory supports that community residents balance the costs and benefits of tourism development, and their support for tourism depends on the outcome of this cost-benefits equation (Andriotis, 2005). Thus, according to Mason (2003), the economic impacts of tourism are the most widely researched impacts of tourism on a destination. Studies by Andereck \& Vogt (2000) also support the findings of the present study. According to their studies, there is a relationship between community residents' support for tourism development and their perception toward tourism impacts. However, it can infer that community leaders' support for community capacity building in tourism development is positively related to their benefits from tourism development. Empirical findings from these studies have suggested that people will act to maximize benefits and minimize costs in different situations. They also weigh total benefits against total costs that effect their decision to participate in tourism decision making and tourism development planning (Kayat, 2002; Lawler, 2001; Yoon et al., 2001). Andriotis \& Vaughan (2003) also found that when the exchange of the economic, social, and environmental resources is at least perceived as balanced by the local communities, only the then tourism is perceived positively by residents. However, they caution that the benefits of tourism may be experienced by only a handful of individuals in the community, and only those who benefit will be more likely to support tourism development. In order to have tourism supported by all community members of the community, the benefits of tourism must be evenly distributed (Andriotis \& Vaughan, 2003).

\section{Conclusion}

By using social exchange theory framework, this paper attempts to illustrate the relationship between perception towards tourism impacts and the level of community capacity building. This theory helps to create a clear understanding about the relationship between perceived impacts and support for tourism development (Perdue et al., 1990). From the study, it is found that the correlation between perception of economic impacts and level of community capacity building is positively significant, whereas the correlation between environmental impacts of tourism and the level of community capacity building is negatively significant. Thus, it could be concluded that the higher the perception of the communities leaders towards the economic impacts, the higher their tendency that to put their effort in building their community capacity in relation to tourism development. On the other hand, if the leaders perceived that tourism could bring environmental damage to their communities, there is a tendency that they will not put their effort in the tourism development. These findings have an implication on the understanding and managing tourism impacts. It is suggested that the well managed tourism can make a positive contribution to destinations, and thus it could received a support from the local communities. As one of the world's largest industries, tourism carries with it significant social, environmental, economic and political impacts. Although tourism can provide significant economic benefits for some destinations, however, the image of tourism as a benign and environmentally friendly industry has often been challenged. There is a clear and growing body of evidence suggests that the effects of tourism development are far more complex than policy-makers usually suggest and that the impacts of tourism occur not just at the destination, but at all stages of a tourist's trip. Furthermore, tourism does not exist in a vacuum. Broader social and environmental changes also shape the form, growth and experience of tourism development. Meanwhile, according to Moscardo (2008), a lack of entrepreneurial capacity, limited understanding of tourism markets and a lack of community understanding of tourism and its impacts have been identified as barriers to effective tourism development in peripheral regions. Thus, the findings of this study could assist community leaders in the design and implementation of tourism development strategies in communities that are undertaking tourism planning.

\section{References}

Andereck, K., \& Vogt, C. (2000). The relationship between residents' attitudes toward tourism and tourism development options. Journal of Travel Research, 39(1), 27-36.

Andriotis, K. (2005). Community Groups' Perceptions of and Preferences for Tourism Development: Evidence from Crete. Journal of Hospitality \& Tourism Research, 29(1), 67-90.

Andriotis, K., \& Vaughan, R. D. (2003). Urban residents' attitudes toward tourism development: The case of Crete. Journal of Travel Research, 42, 172-185.

Ap, J. (1992). Residents' perceptions on tourism impacts. Annals of Tourism Research, 19(4), 665-690. 
Aref, F., \& Ma'rof, R. (2009). Community Leaders' Characteristics and their Effort in Building Community Capacity for Tourism Development in Local Communities. International Journal of Business and Management, 4(10).

Aref, F., Ma'rof, R., \& Sarjit, S. G. (2009). Community Perceptions toward Economic and Environmental Impacts of Tourism on Local Communities. Asian Social Science, 5(7), 130-137.

Ary, D., Jacobs, C., \& Rezavieh, A. (1996). Introduction to research in education (5 ed.). New York: Harcourt Brace College Publishers.

Chaudhary, M., Kamra, K. K., Boora, S. S., Kumar, R. B., Chand, M., \& Taxak, R. H. (Eds.). (2007). Tourism Development : Impacts and Strategies. New Delhi: Vedams eBooks (P) Ltd.

Chen, J. S. (2000). An investigation of urban residents' loyalty to tourism. Journal of Hospitality and Tourism Research, 24, 5-19.

Chen, J. S. (2001). Assessing and visualizing tourism impacts from urban residents' perspectives. Journal of Hospitality and Tourism Research, 25, 235-250.

Chon, K. S. (2000). Tourism in Southeast Asia: a new direction. New York: Haworth Hospitality Press.

Cultural Heritage News Agency. (2006). Shiraz to be registered in UNESCO's city of literature. Retrieved 1.April, 2008, from http://www.chnpress.com/news/?section=2\&id=6162CHN(Cultural

Eyler, A., Mayer, J., Rafi, R., Housemann, R., Brownson, C., \& King, C. (1999). Key informant surveys as a tool to implement and evaluate physical activity interventions in the community. Health Education Research, 14(2), 289.

Grover, R., \& Vriens, M. (2006). The handbook of marketing research: uses, misuses, and future advances: Sage Publications.

Gursoy, D., Jurowski, C., \& Uysal, M. (2002). Resident attitudes: A Structural Modelling Approach. Annals of Tourism Research, 29(1), 79-105.

Gursoy, D., \& Rutherford, D. G. (2004). Host attitudes toward tourism: An Improved Structural Model. Annals of Tourism Research, 31(3), 495-516.

Harrill, R. (2004). Residents' attitudes toward tourism development: A literature review with implications for tourism planning. Journal of Planning Literature, 18(3), 251-266.

Jurowski, C., Uysal, M., \& Williams, R. (1997). A theoretical analysis of host community resident reactions to tourism. Journal of Travel Research, , 36(2), 3.

Kayat, K. (2002). Power, social exchanges and tourism in Langkawi: Rethinking resident perceptions. The International Journal of Tourism Research, 4(3), 171-191.

Lawler, E. J. (2001). An affect theory of social exchange. The American Journal of Sociology, 107(2), 321-325.

Limbert, J. W. (2004). Shiraz in the age of Hafez: the glory of a medieval Persian city. Seattle: University of Washington Press.

Martin, B., McGuire, F., \& Allen, L. (1998). Retirees' attitudes toward tourism: Implications for sustainable development. Tourism Analysis, 3, 43-51.

Mason, P. (2003). Tourism impacts, planning and management. Jordan Hill, Oxford: Butterworth-Heinemann.

Ming, G. a., \& Wong, P. P. ( 2006). Residents' Perception of Tourism Impacts: A Case Study of Homestay Operators in Dachangshan Dao, North-East China. Tourism Geographies, 8(3), 253 - 273.

Moscardo, G. (Ed.). (2008). Building community capacity for tourism development. Australia.

Moutinho, L. (Ed.). (2000). Strategic management in tourism. University of Glasgow Business School, UK: CABI Publishing

Nyaupane, G. P., \& Thapa, B. (2006). Perceptions of environmental impacts of tourism: A case study at ACAP, Nepal. The International Journal of Sustainable Development and World Ecology, 13(1), 51-61.

Perdue, R. R., Long, P. T., \& Allen, L. (1990). Resident support for tourism development. Annals of Tourism Research, 17(4), 586-599.

Sharma, K. k. (2004). Tourism And Socio-cultural Development. New Delhi: Sarup and Sons.

Singh, S., Timothy, D. J., \& Dowling, R. K. (Eds.). (2003). Tourism in destination communities. Cambridge, USA: CABI publishing. 
Thompson, B., Lichtenstein, E., Corbett, K., Nettekoven, L., \& Feng, Z. (2000). Durability of tobacco control efforts in the 22 community Intervention trial for smoking cessation (COMMIT) communities 2 years after the end of intervention. Health Education Research, 15(3), 353-366.

Vogt, C. A., \& Jun, S. H. (2004). Residents' attitudes toward tourist market segments and tourism development in Valdez, Alaska: A comparison of residents' perceptions of tourist impact on the economy and quality of life. Paper presented at the Proceedings from the 2004 Northwest Recreation Research Symposium.

Von Kroff, M., Wickizer, T., Maeser, J., O'Leary, P., Pearson, D., \& Beery, W. (1992). Community activation and health promotion: identification of key organizations. American Journal of Health Promotion, 7, 110-117.

Wang, Y., \& Pfister, R. E. (2008). Residents' Attitudes Toward Tourism and Perceived Personal Benefits in a Rural Community. Journal of Travel Research, 47, 84-93.

Yoon, Y., Gursoy, D., \& Chen, J. (2001). Validating a tourism development theory with structural equation modelling. Tourism Management, 22(4), 363-372.

Table 1. Means and Standard Deviation of the studied Variables

\begin{tabular}{lcc}
\multicolumn{1}{c}{ Variables } & Mean & Standard Deviation \\
\hline \hline Perception towards cultural impact & 37.77 & 3.114 \\
Perception towards economic impacts & 17.24 & 2.346 \\
Perception towards environmental impacts & 17.45 & 2.935 \\
Total perception & 72.46 & 6.002 \\
Community capacity building & 81.02 & 23.763 \\
\hline \hline
\end{tabular}

Table 2. Pearson Correlation Matrix among Tourism Impacts and Level of CCB

\begin{tabular}{|c|c|c|c|c|c|}
\hline & 1 & 2 & 3 & 4 & 5 \\
\hline 1-Socio-cultural impacts & 1 & & & & \\
\hline 2. Environmental impacts & $.354 * *$ & 1 & & & \\
\hline 3. Economic impacts & $.166^{*}$ & $.240 *$ & 1 & & \\
\hline 4. Total impacts & $.757 * *$ & $.767 * *$ & $.594 * *$ & 1 & \\
\hline 5. Community capacity building & -.092 & $-.257 * *$ & $.252 * *$ & -.075 & 1 \\
\hline
\end{tabular}

$* P<.05 \quad * * p<.01$

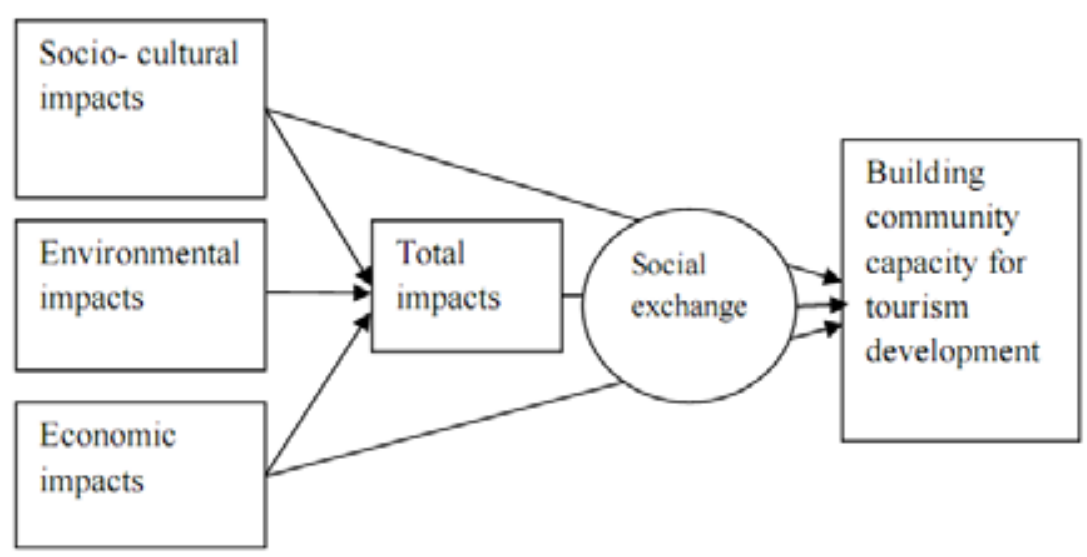

Figure 1. Tourism Impacts and Support for Community Capacity Building in Tourism Development 